\title{
Origin of the Tendon of the Long Head of the Biceps Brachii Muscle and its Relationship with Glenoid Labrum in Human Foetuses
}

\author{
Origen del Tendón de la Cabeza Larga del Bíceps Braquial \\ y sus Relaciones con el Labro Glenoideo en Fetos Humanos
}

"Francisco Prado Reis; *,** José Aderval Aragão; *** Gustavo Souza Moura; ****úri Amorim de Santana; ${ }^{* * * * *}$ Eric Allan Nunes Carvalho; ${ }^{* * * * *}$ Vera Lúcia Corrêa Feitosa \& ${ }^{* * * * * *}$ Marco Antonio Prado Nunes

REIS, F. P.; ARAGÃO, J. A.; MOURA, G. S.; DE SANTANA, I. A.; CARVALHO, E. A. N.; FEITOSA, V. L. C. \& NUNES, M. A. P. Origin of the tendon of the long head of the biceps brachii muscle and its relationship with glenoid labrum in human foetuses. Int. $J$. Morphol., 27(1):169-172, 2009.

SUMMARY: We dissected the shoulders of 20 human foetuses to anatomical study. The purpose of this study was to characterize the anatomical origin of the long head tendon of the muscle biceps brachii (LHBBT) in human foetuses and its relationships with the glenoid labrum of the scapula. The results had shown that in approximately $95 \%$ of the cases the tendon of the long head of the biceps brachii inserts in the region of the glenoid labrum. This origin seems to form, together with the glenoid labrum, an anatomical complex. We conclude that the almost totality of the LHBBT was originated in the glenoidal labrum. For us, this furthermore reinforce the importance and necessity of better clarifying the anatomical and clinical implications of the biceps/labrum complex.

KEY WORDS: Anatomy; Biceps brachii muscle; Glenoid labrum.

\section{INTRODUCTION}

The descriptions of the origin of the long head of the biceps brachii tendon (LHBBT) in the majority of texbooks texts and in anatomical works show disagreements, in special, as the relationships of the tendon with the glenoid labrum of the scapula. Anatomical variations of the glenoid bicipital/ labrum complex and the continuity of the superior labrum with the tendon have been described (Vangsness et al., 1994; Prescher et al., 2000). Arthroscopy studies have admitted that the LHBBT plays an important role in the properly functioning shoulder and in the pathologic mechanism of action in the superior desinsertion of the glenoid labrum (Andrews et al., 1985; Terry et al., 1994; Maffet et al., 1995; Jee et al., 2001). According to Gray (1977), Moore (2001), Di Dio (2002) the LHBBT originates in the supraglenoid tubercle. For Bergman et al. (2004), usually the tendon inserts in the glenoid labrum. Testut \& Latarjet (1954) had admitted the origin of the tendon in the external angle of the scapula, immediately above of the glenoidal socket. Most of the authors admits that beyond of the origin to the level of the supraglenoid tubercle, the LHBBT participates or even inserts in glenoid labrum (Cruveilhier, 1844; Poirier et al., 1909; Testut \& Latarjet, 1981; Gardner et al., 1988; Sappey, 1989; Williams \& Warwick, 1980; Cooper et al., 1992; Vangsness et al.; Demondion et al., 2001).

In arthroscopic examinations, the assessment of the origin of the LHBBT at the supraglenoid tubercle or labrium is important (Vangsness et al.). Snyder et al. (1990) was whom first described the SLAP (superior labial, anterior and posterior) lesions. That may be detected if the stability of the biceps/labrum complex is compromised or if the biceps and labrium are frayed.

Our objective was characterize the anatomical origin of the LHBBT in human foetuses and its relationships with the glenoid labrum of the scapula.

\footnotetext{
* Universidade Tiradentes (UNIT), Brasil.

${ }^{* *}$ Universidade Federal de Sergipe (UFS), Brasil.
} 


\section{MATERIAL AND METHOD}

We studied 20 shoulders from human foetuses of both sexes from the Department of Morphology of Federal University of Sergipe. These fetuses were obtained in accordance with the law number 8501 of 1992 that deals with on the use to cadavers for studying and research. The foetuses had been fixed in a solution of formol $10 \%$ and were dissected without aid of optic instruments. In the dissection, the capsule of the joint of the shoulder, after displayed, was open, thus allowing accompaniment the trajectory of the LHBBT until its proximal insertion. All the dissected shoulders were photographed after the identification of the proximal insertion of the tendon.

\section{RESULTS}

In 19 of the 20 shoulders studied, the origin of the LHBBT occurred in the posterior level of the glenoid labrum (Fig. 1). Starting from this insertion, the tendon followed a anterior direction, crossed the head of the humerus and emerged of the articular capsule. At long of the humerus was covered by intertubercular ridge of this bone and finally arrive the muscular fibres of the long head of the biceps brachii muscle. In two cases it was observed that the tendon crossed a canal formed between the tendon of the pectoralis major muscle and the bicipital fascia. In only one of the cases, the origin of the LHBBT was found in the supraglenoid tubercle of the right scapula of a male foetus (Fig. 2).

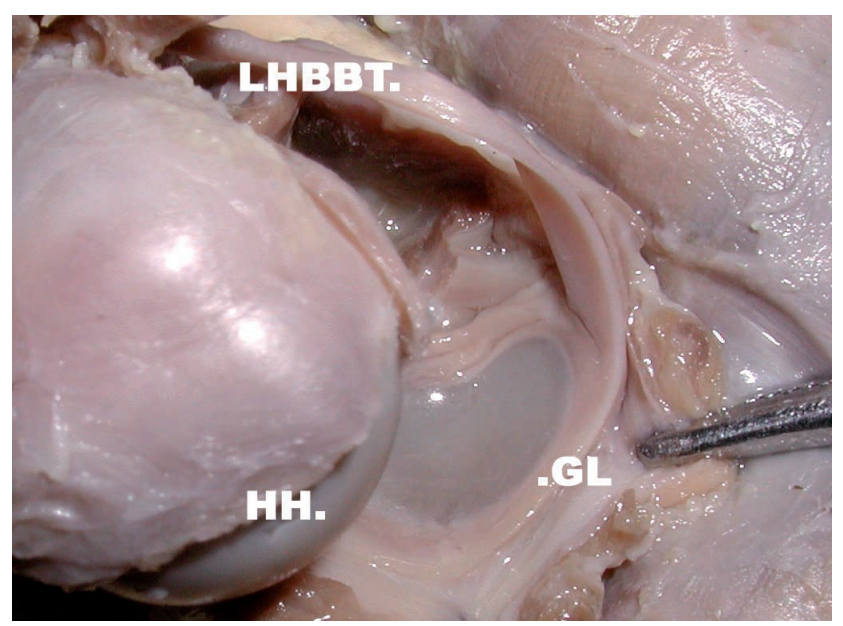

Fig. 1. origin of the long head of the biceps brachii tendon in the posterior level of the glenoid labrum. LHBBT - long head of the biceps brachii tendon; GL - glenoid labrum; HH - humerus head.

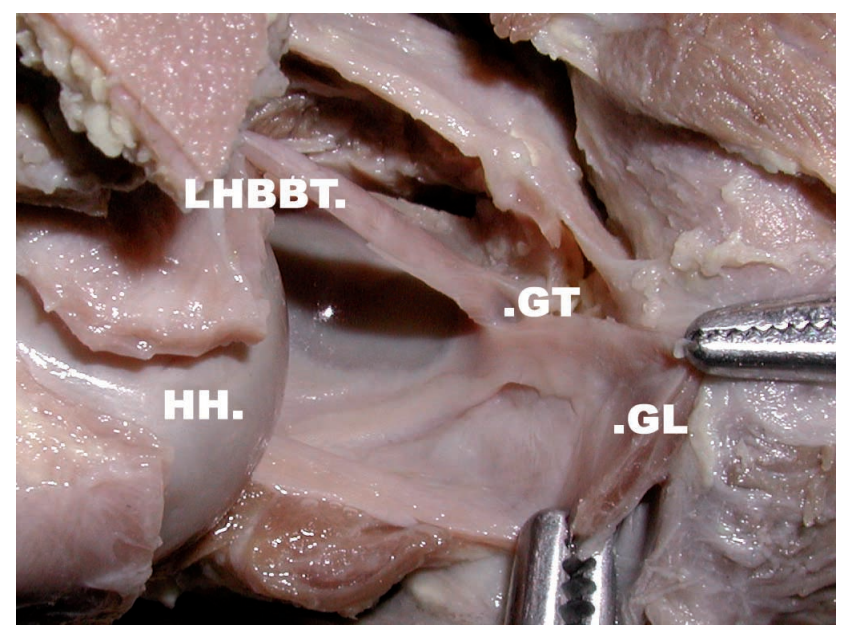

Fig. 2. Origin of the long head of the biceps brachii tendon in the supraglenoid tubercle. LHBBT - long head of the biceps brachii tendon; GL - Glenoid labrum; HH - humerus head; GT supraglenoid tubercle.

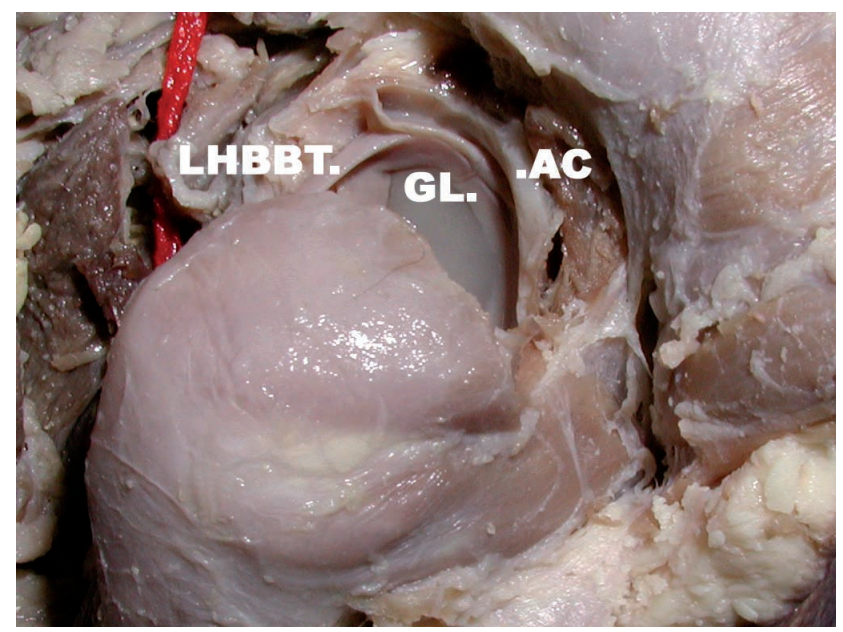

Fig. 3. Glenoid labrum divisions. LHBBT - long head of the biceps brachi tendon; GL - glenoid labrum; AC - articular capsule.

In two glenoid labrums ocurred a division of the labrum being that where one was related with the tendon and the another with a like ligament structure that seems incorporated the joint capsule (Fig. 3).

\section{DISCUSSION}

Our study shows that $95 \%$ of the origin of the LHBBT occurred in the glenoidal labrum. This number of the our findings was superior to the describes by authors as Bankart (1938), De Palma et al. (1949), Williams \& Warwick, Detrisac \& Johnson (1986), Pal et al. (1991), Cooper et al. and Vangsness et al. In disagreement with Hollinshead 
REIS, F. P.; ARAGão, J. A.; MOURA, G. S.; DE SANTANA, I. A.; CARVALHO, E. A. N.; FEITOSA, V. L. C. \& NUNES, M. A. P. Origin of the tendon of the long head of the biceps brachii muscle and its relationship with glenoid labrum in human foetuses. Int. J. Morphol., 27(1):169-172, 2009.

(1958), Hammond et al. (1971), Williams \& Warwick and Last (1984), we did not find the LHBBT exclusively inserted in the supraglenoidal tubercle. In only one case the LHBBT was inserted in the supraglenoidal tubercle.

Healey et al. (2001) emphasized the constitution of the biceps/labrum complex in the anterior shoulder stability. The authors yet claim about the relative few anatomic studies specific to the superior glenoidal labrum and the LHBBT origin. We observe that at least one third of the posteriorsuperior region of the labrum, macroscopically was indistinguishable of the LHBBT. Histologic (Cooper et al.) and ultra-estrutural (Nishida et al., 1996) studies stand out aspects of this complex.

Since Snyder et al., biceps/labrum complex (Healey et al.), the injury of the antero-posterior-superior glenoid labrum (SLAP) had been attributed to the possible irregularities of the relationship between the labrum and the LHBBT. Experimentally, Bey et al. (1998), demonstrated the importance of the posterior-superior region of the glenoid labrum in the transmission of forces through the LHBBT during effort and movement of the shoulder.

Demirkan et al. (2003) pointed out that an understanding of the normal anatomy and biomechanics of the shoulder joint is essential for proper interpretation of the MRI infestations of those conditions.

We conclude that the almost totality of the LHBBT was originated in the glenoidal labrum. For us, this furthermore reinforce the importance and necessity of better clarifying the anatomical and clinical implications of the biceps/labrum complex.

REIS, F. P.; ARAGÃO, J. A.; MOURA, G. S.; DE SANTANA, I. A.; CARVALHO, E. A. N.; FEITOSA, V. L. C. \& NUNES, M. A. P. Origen del tendon de la cabeza larga del bíceps braquial y de sus relaciones con el labro glenoídeo en fetos humanos. Int. J. Morphol., 27(1):169-172, 2009.

RESUMEN: Fueron disecados los hombros de 20 fetos humanos con el propósito de hacer un estudio anatómico. El objetivo de este estudio fue cdeterminar el origen del tendón de la cabeza larga del músculo bíceps braquial en fetos humanos y sus relaciones con el labro glenoídeo. Los resultados demostraron que, en cerca del 95\% de los casos, el tendón de la cabeza larga del músculo bíceps braquial estaba originándose en la región del labro glenoídeo. Este origen parece formar junto, con el labro glenoideo, un complejo anatómico. Concluimos que casi todos de los tendones del músculo bíceps braquial están insertados en el labro glenoideo. Esto es importante conocer para una mejor clarificación de las implicaciones clínico-anatómicas del complejo del bíceps/labro.

PALABRAS CLAVE: Anatomía; Músculo esquelético; Articulación humeral.

\section{REFERENCES}

Andrews, J. R.; Carson, W. G. \& McLeod, W. D. Glenoid labrum tears related to the long head of the biceps. Am. J. Sports Med., 13(5):337-41, 1985.

Bankart, A. S. B. Pathology ant treatment of recurrent dislocation of shoulder-joint. Br. J. Surg., 26:23-9, 1938.

Bergman, G. J.; Winters, J. C.; Groenier, K. H.; Pool, J. J.; Meyboom-de Jong, B.; Postema, K. \& van der Heijden, G. J. Manipulative therapy in addition to usual medical care for patients with shoulder dysfunction and pain: a randomized, controlled trial. Ann. Intern. Med., 141(6):432-9, 2004.

Bey, M. J.; Elders, G. J.; Huston, L. J.; Kuhn, J. E.; Blasier, R. B. \& Soslowsky, L. J. The mechanism of creation of superior labrum, anterior, and posterior lesions in a dynamic biomechanical model of the shoulder: the role of inferior subluxation. J. Shoulder Elbow Surg., 7(4):397-401, 1998.
Cooper, D. E.; Arnoczky, S. P.; O'Brien, S. J.; Warren, R. F.; DiCarlo, E. \& Allen, A. A. Anatomy, histology, and vascularity of the glenoid labrum. An anatomical study. J. Bone Joint Surg. Am., 74(1):46-52, 1992.

Cruveilhier, J. The Anatomy of the Human Body. $3^{\text {rd }}$ Ed. New York, Harper, 1844.

Demirkan, A. F.; Sargon, M. F.; Erkula, G. \& Kiter, E. The spinoglenoid ligament: an anatomic study. Clin. Anat., 16(6):511-3, 2003.

Demondion, X.; Maynou, C.; Van Cortenbosch, B.; Klein, K.; Leroy, X. \& Mestdagh, H. Relationshipship between the tendon of the long head of the biceps brachii muscle and the glenoid labrum. Morphologie, 85(269):5-8, 2001.

De Palma, A. F.; Callery, G. \& Bennett, G. A. Variational anatomy and degenerative lesions of the shoulder joint. Instr. Course Lect., 6:255-81, 1949. 
REIS, F. P.; ARAGÃO, J. A.; MOURA, G. S.; DE SANTANA, I. A.; CARVALHO, E. A. N.; FEITOSA, V. L. C. \& NUNES, M. A. P. Origin of the tendon of the long head of the biceps brachii muscle and its relationship with glenoid labrum in human foetuses. Int. J. Morphol., 27(I):169-172, 2009.

Detrisac, D. A. \& Johnson, L. L. Arthroscopic shoulder anatomy: Pathology and surgical implications. New Jersey, Slack, 1986.

Di Dio, L. J. A. Tratado de Anatomia aplicada. $2^{\mathrm{a}}$ ed. São Paulo, Póluss Editorial, 2002.

Gardner, E.; Gray, D. J. \& Rahilly, R. O. Anatomia. $4^{\mathrm{a}}$ ed. Rio de Janeiro, Guanabara Koogan, 1988.

Gray, H. Anatomia. Goss, C. M. (ed.). Rio de Janeiro, Guanabara Koogan, 1977.

Hammond, G.; Torgerson, W. R.; Dotter, W. E. \& Leach, R. E. The painful shoulder. Instr. Course Lect., 28:83-90, 1971.

Healey, J. H.; Barton, S.; Noble, P.; Kohl, H. W. \& Ilahi, O. A. Biomechanical evaluation of the origin of the long head of the biceps tendon. Arthroscopy, 17(4):378-82, 2001.

Hollinshead, W. H. Anatomy for surgeons. New York, Hoeber-Harper, 1958.

Jee, W. H.; McCauley, T. R.; Katz, L. D.; Matheny, J. M.; Ruwe, P. A. \& Daigneault, J. P. Superior labral anterior posterior (SLAP) lesions of the glenoid labrum: reliability and accuracy of MR arthrography for diagnosis. Radiology, 218(1):127-32, 2001.

Last, R. J. Anatomy: Regional and applied. Edinburgh, Churchill Livingstone, 1984.

Maffet, M. W.; Gartsman, G. M. \& Moseley, B. Superior labrum-biceps tendon complex lesions of the shoulder. Am. J. Sports Med., 23(1):93-8, 1995.

Moore, K. L. Anatomia orientada para clínica. $3^{\text {a }}$ ed. Rio de Janeiro, Guanabara Koogan, 2001.

Nishida, K.; Hashizume, H. \& Toda, K. Histologic and scanning electron microscopic study of the glenoid labrum. J. Shoulder Elbow Surg., 5:132-8, 1996.

Pal, G. P.; Bhatt, R. H. \& Patel, V. S. Relationshipship between the tendon of the long head of biceps brachii and the glenoidal labrum in humans. Anat. Rec., 229(2):278-80, 1991.

Poirier, P.; Charpy, A. \& Cuneo, B. Traite d'anatomie humaine. $2^{\text {nd }}$ ed. Paris, Masson, 1909.
Prescher, A. Anatomical basics, variations, and degenerative changes of the shoulder joint and shoulder girdle. Eur. J. Radiol., 35(2):88-102, 2000.

Sappey, P. C. Traité D’Anatomie Descriptive. Tome III. Paris, Lecrosnier et Babé, 1989.

Snyder, S. J.; Karzel, R. P.; Del Pizzo, W.; Ferkel, R. D. \& Friedman, M. J. SLAP lesions of the shoulder. Arthroscopy, 6(4):274-9, 1990.

Terry, G. C.; Friedman, S. J. \& Uhl, T. L. Arthroscopically treated tears of the glenoid labrum. Factors influencing outcome. Am. J. Sports Med., 22(4):504-12, 1994.

Testut, L. \& Latarjet, A. Compendio de anatomia descriptiva. $22^{\mathrm{a}}$ ed. Buenos Aires, Salvat, 1981.

Testut, L. \& Latarjet, A. Tratado de Anatomía Humana. $9^{\text {a }}$ ed. Barcelona, Salvat, 1954.

Vangsness, C. T.; Jorgenson, S. S.; Watson, T. \& Johnson, D. L. The origin of the long head of the biceps from the scapula and glenoid labrum. An anatomical study of 100 shoulders. J. Bone Joint Surg. Br., 76(6):951-4, 1994.

Williams, P. L. \& Warwick, R. Gray's anatomia. Thirthysixth ed. Edinburgh, Churchill Livingstone, 1980.

Correspondence to:

Francisco Prado Reis

Rua Silvio César Leite, 301

Apt 1203, Bairro Salgado Filho

Cep: 49020-060

Aracaju, Sergipe

BRAZIL.

E-mail: pradoreis@sergipenet.com.br

Received: 16-07-2007

Accepted: 09-10-2008 